Economic \&

( )

0

ก

ST/ESA/2003/DP. 32

บ

DESA Discussion Paper No. 32
I

$\rightarrow$

(1)

\title{
Universal Pensions in Mauritius: Lessons for the Rest of Us
}

\section{Larry Willmore}

April 2003

United Nations 


\section{DESA Discussion Paper Series}

DESA Discussion Papers are preliminary documents circulated in a limited number of copies and posted on the DESA web site

http://www.un.org/esa/papers.htm to stimulate discussion and critical comment. This paper has not been formally edited and the designations and terminology used do not imply the expression of any opinion whatsoever on the part of the United Nations Secretariat. Citations should refer to a "Discussion Paper of the United Nations Department of Economic and Social Affairs."

\section{Larry Willmore}

The author is Economic Affairs Officer in the Division for Public Administration and Development Management of the Department of Economic and Social Affairs. This paper was presented to the $4^{\text {th }}$ International Research Conference on Social Security, organized by the International Social Security Association in Antwerp, Belgium, 5-7 May 2003.

Comments should be addressed to the author, c/o Division for Public Economics and Public Administration, Room DC2-1446, United Nations, New York, NY, 10017, or by e-mail to willmore@un.org. Additional copies of the paper are available from the same address.

Authorized for distribution by:

\section{Guido Bertucci}

Director

Division for Public Administration and

Development Management

Room DC2-1714

United Nations

New York, NY 10017

Phone: (212) 963-5761/Fax: (212) 963-9681

Email: bertucci@un.org

\section{United Nations \\ Department of Economic and Social Affairs}




\begin{abstract}
That the Government of Mauritius provides nearly every resident over the age of 60 with a non-contributory, basic pension is one of the best-kept secrets in the world. The scheme dates from 1950 and became universal in 1958, following abolition of a means test. Remarkably, introduction of a compulsory, contributory scheme for workers in the private sector appears to have strengthened the non-contributory regime without affecting its universality. This paper examines the past and future of non-contributory, universal pensions in Mauritius, and draws lessons that might be useful for other countries, especially those in the developing world.
\end{abstract}

Keywords: public pensions, social security, means test, targeting, demographic ageing, Mauritius

JEL Classification: H55 


\section{INTRODUCTION}

"The old age pensioner has throughout the years paid taxes on commodities he has consumed as everybody else has. He has paid taxes on tea, sugar, tobacco, matches, rice, pulses, dried fish, rum, calico, khaki, everything he has consumed and used to be able to live as a useful member of our society. One way or another he has contributed to the national budget. The Old Age Pension scheme being financed out of public funds is [thus] a contributory one. The applicant for Old Age Pension has already paid in his contributions."

F.S. Chadien, recorded in Debates of the Legislative Council of Mauritius, 25 June 1957.

Mauritius is a small, subtropical country located in the Indian Ocean to the east of Madagascar. It was occupied successively by the Dutch in 1598 , the French in 1715 and the British in 1810. As a British colony, it was increasingly selfgoverning after 1947. The constitution of that year gave voting rights to all adults, including women, subject to a test of "simple literacy". Universal suffrage was introduced in 1958 and Mauritius became a full, sovereign state in 1968 .

At the time of its independence, Mauritius suffered from excess population, high unemployment and a low standard of living. In this stagnant plantation economy, a single crop-sugar-accounted for $90 \%$ of export earnings. Sugar continues to dominate, even today, but, beginning in the 1980 s, its relative importance dropped markedly because of increased foreign exchange earnings from exports of light manufactures (primarily garments) and from tourism. Growth since 1980 has been persistent and strong, so strong that some refer to it as a "Mauritian Miracle" (Subramanian and Roy 2001). Life expectancy at birth has reached 71 years, $84.5 \%$ of the adult population is literate, and income per capita, measured on a purchasing power parity (PPP) basis, is $40 \%$ that of the USA. ${ }^{1}$ The 1.2 million residents of Mauritius now have the standard of living of a middle-income developing country, and the country ranks 67th (between Saint Lucia and Colombia) out of 173 countries listed in the Human Development Report of the UNDP (2002). A consequence of this successful development has been a decrease in the birth rate and an increase in the number of elderly persons in the population: on reaching age 60 , a Mauritian male can expect to live another 15 years and a woman an additional 20 years (Mauritius Central Statistical Office, 1999, p. 38).

Much of this is well known. What is less known is that every elderly resident of Mauritius receives income support from a system of noncontributory pensions that dates from $1950 .^{2}$ Subject only to minimum residence requirements (12 years from age 18 for citizens, 15 years from age 40 for non-citizens), every resident aged 60 or over is eligible for a monthly pension that amounts, in the current fiscal year $(2002 / 2003)$ to the following ${ }^{3}$ :

- $\quad$ age 60-89: Rs 1,700 (USD 58)

- age 90-99: Rs 6,400 (USD 220)

- age 100+: Rs 7,300 (USD 252)

Those who are totally blind or suffer from total

\footnotetext{
1 Another densely populated, former colonySingapore-has done even better, and now has a per capita income equal to $80 \%$ that of the USA. These PPP estimates are for the year 2000 and are from Penn World Table version 6.1 (Heston, Summers and Aten, 2002). UNDP (2002, pp. 149-152) reports, for the same year, PPP per capita incomes for Singapore and Mauritius equal only to $68 \%$ and $29 \%$, respectively, that of the USA, but the UNDP team did not have access to the latest Penn World Table at the time it drafted its report.

2 I myself was unaware of this long history, and erroneously reported (Willmore 2001) that the universal pension scheme of Mauritius began with passage of the National Pensions Act of 1976.

${ }^{3}$ The US dollar equivalents shown are calculated at the market exchange rate. The US dollar does, of course, have more purchasing power in Mauritius than in the USA or other high-income countries.
} 
paralysis receive an additional benefit of Rs 1,205 a month. ${ }^{4}$ It is also customary to pay all pensioners a " $13^{\text {th }}$ month" bonus at the end of each year. As a proportion of per capita GDP, these pensions range from approximately $18 \%$, for the smallest and most common pension, to $92 \%$ for that of a person aged 100 years or more and severely disabled.

These basic pensions are not income-tested, nor are they retirement-tested. They are taxable as ordinary income, however, so those who continue to work, or have other sources of income, return some of their pension to the government in the form of tax. All pensioners aged 90 years or more pay some income tax, even if they have no other income, unless they have deductions for dependents or other allowable expenses. The rate of income tax in Mauritius is now nearly flat, with only two brackets: $15 \%$ for the first Rs 25,000 of taxable income, and $25 \%$ for all additional income. The basic personal deduction is Rs 60,000, equivalent to income of Rs 5,000 a month. In addition, all consumers, pensioners and workers alike, pay value added tax (VAT) on most goods and services, at a rate of 12 percent.

The history of universal pensions in Mauritius is not readily available and is incomplete even in this paper, which is a work in progress. For this reason the paper contains more details than may be welcomed by casual readers. Such readers may want to skim or skip the next section, as well as section 5, titled "Contributory, income-related pensions (from 1978)." The other three sections are of general interest, as is the conclusion.

\footnotetext{
${ }^{4}$ In mid-1997, $11 \%$ of all pensioners, including $39 \%$ of those over age 80 , were blind or paralysed, so qualified for a disability supplement (Mauritius Central Statistical Office, 1999, p. 35).
}

\section{NON-CONTRIBUTORY, BASIC PENSIONS (FROM 1950)}

The British Governor of Mauritius became concerned that workers in the colony were relying on Government for relief in their old age, so appointed in January of 1940 a Social Insurance Committee to look into the possibility of implementing a system of old age pensions. In January of 1941, the Committee concluded that it was "inequitable that the full responsibility of providing for the aged should be transferred entirely from the family to the taxpayer. The breakdown of the old system demands that it should be replaced by a new one based on the principle of 'self-help' and the most practicable means of ensuring this is a contributory pension scheme" (unpublished Report of the Social Insurance Committee, quoted in Titmuss and Smith, 1961, p. 85).

The Social Insurance Committee recommended a compulsory system of flat contributions ( 6 cents per day of work, divided equally -2 cents each-among the worker, the employer, and the Government), with benefits strictly proportional to contributions paid. The programme targeted the poor, so would exclude those with an annual income of Rs 600 or more. One member of the Committee (Dr. E. Millien, who represented the "coloured community"5) wrote a lengthy dissenting report, accusing his colleagues of attempting to shift the cost of old age relief from the taxpayer to workers, who were desperately poor and could not afford to pay contributions (Titmuss and Smith, 1961, p. 86). The Government Actuary of Great Britain in 1943 questioned many details of the Committee's proposal, even whether the Colony could afford social insurance, but agreed that any scheme adopted should be "not a scheme of

\footnotetext{
5 "Coloured community" was used at that time to refer to descendants of African slaves, the vast majority of whom were living in poverty. The Social Insurance Committee included also a representative of Indian labour, who did not support Dr. Millien. The remaining six members of the Committee represented the interests of employers, insurance companies, and Government (Mauritius, 1948, p. 3).
} 
non-contributory pensions subject to a means test ... but a scheme of pensions payable as of right and financed...by insurance contributions" (Mauritius, 1948, p. 7).

By 1950 , there was still no system of contributory pensions in place, so Government tabled on 21 March of that year legislation for a non-contributory system, intending it as a stopgap measure to be used until a 'proper' system of social insurance could be set up. The intent was to begin payments of pensions in April 1950, but these did not actually commence until September, with arrears paid from 1 July. The qualifying age was set at 65 , and the maximum monthly pension of Rs 15 (Rs 5 more than "outdoor relief") was reduced by the full amount of income from other sources. This strict means test caused much resentment, so in December 1950 the income ceiling was raised to Rs 30 a month (the first Rs 15 of income was disregarded).

In 1953 the Old Age Pensions Bill was amended to reduce the qualifying age for women from 65 to 60 years, increase the maximum pension to Rs 20 a month, change the income test from a monthly to an annual basis, and raise the income ceiling to Rs 35 (Rs 420 a year). Pensioners at the end of 1953 numbered 19,000, and would have reached 24,000, had the means test not excluded 5,000 elderly persons. (See figure 1 and appendix A.)

Non-contributory, basic pensions were popular and functioned smoothly, yet Government never abandoned its dream of replacing them with a contributory system. The Governor appointed a Committee of Ministers that recommended, in September of 1957, implementation of a system that would be flat rate, contributory and compulsory. This was a system identical to the one proposed by the Social Insurance Committee in 1941, except that contributions would be payable weekly rather than daily, and would be collected from all workers younger than 60 , even - at reduced rates - from child workers aged 14 to 18
(Titmuss and Smith, 1961, pp. 89-90). ${ }^{6}$

Government failed to follow up on the recommendations of the Committee of Ministers. Instead, the Minister of Health and Social Services, in response to a question from the floor of the Legislative Council, made a surprising announcement on 13 December 1957 that Government had decided to abolish the means test for old age pensions. The minister also announced that the monthly pension would increase from Rs 20 to Rs 22, to be paid retroactively from July 1957.

The abolition of the means test in 1958 added approximately 6,000 to the number of old age pensioners, who came to total 25,783 at the end of 1958. Universal, basic pensions cost Government one percent of GDP in that year. The minister responsible for administering old age pensions alleged that a portion of the increased costs were offset by reduced costs of administration, but he was unable to quantify the savings. Pensions were taxable as income, so a portion was also recovered, or 'clawed back' from the wealthy. A pensioner in the highest tax bracket retained, in 1958, only 4 rupees of a 22 rupee pension. Government did not quantify these savings, either.

At the historic moment of extending old age pensions to everyone, Government Ministers were apologetic, insisting that the measure was temporary, that it would be dismantled once a proper system of contributory pensions was in place. The Minister of Health and Social Services confidently informed the legislature that 'in less than two years' time, there would be established in this country a complete and comprehensive social security scheme, contributory this time, by which the amount of old age benefit is going to be higher...." He added, "There will be of course no burden

\footnotetext{
Titmuss and Smith (1961, pp 107-111) also recommended compulsory, contributory pensions, but would exclude, at least initially, low-paid and unskilled workers, who could make do with a basic pension. These contributory pensions were designed to supplement universal, non-contributory pensions, not to replace them.
} 


\section{Figure 1. Coverage of Basic Pensions in Mauritius (thousands of persons, 1950-2001)}

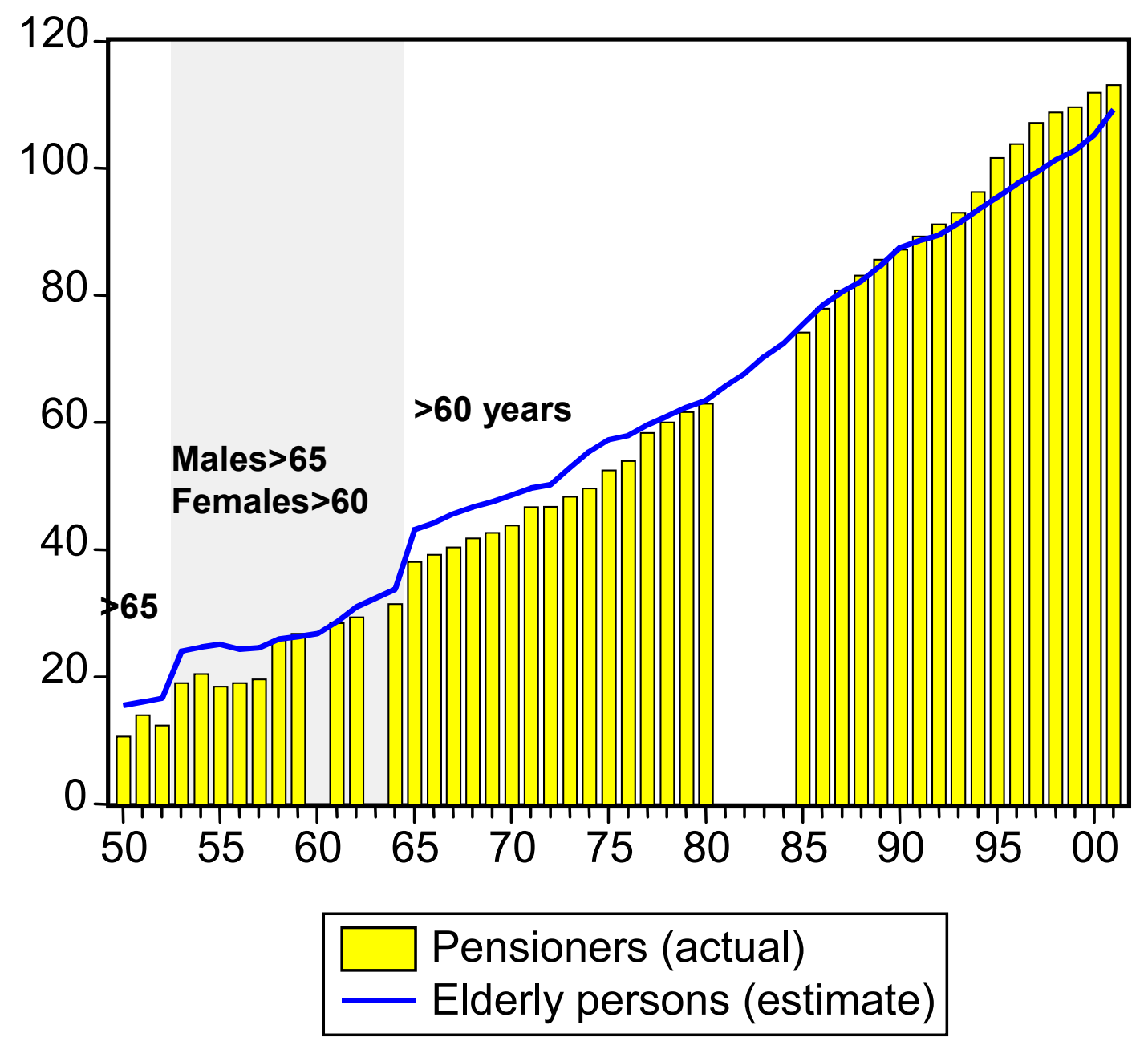

Source: Appendix A.

Note: Data are end-year through 1971, mid-year from 1972. Pensioner data missing for 1960, 1963 and 1981-84.

placed on the coming generations as soon as this contributory scheme is introduced. This present measure, I repeat, is but temporary so far as it is non-contributory and also as far as the amount of Rs 22 is concerned" (recorded in Mauritius, Debates, 8 April 1958).

Contributory pensions were introduced, not in 1960, but much later, in the year 1978. To date, they have not replaced universal, noncontributory pensions. I postpone discussion of this parallel system of pensions until section 5, in order to focus first on non-contributory pensions.

In 1965 Government lowered the qualifying age to 60 years for everyone and, at the same time, re-introduced a mild form of means 


\section{Figure 2. Real Average Basic Pension in Mauritius (index, 1995=100)}

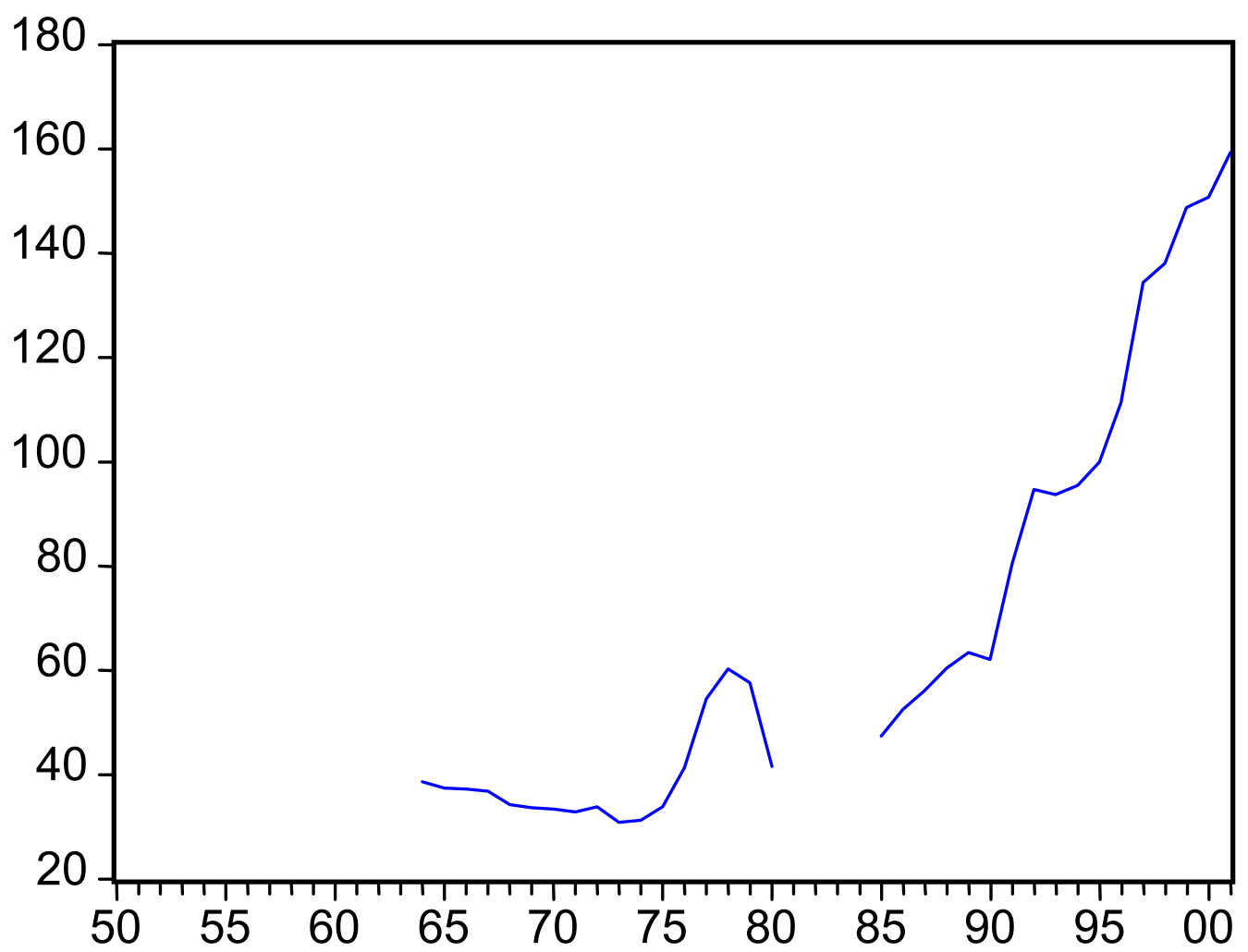

\section{Source: Appendix A.}

Note: Nominal pension deflated by consumer price index. Consumer price index missing for 1950-1962. Pension data missing for 1981-84.

testing: elderly persons with sufficient income to be subject to payment of tax were disqualified. ${ }^{7}$ The basic pension remained at Rs 22 a month for more than 14 years, until it was increased to Rs 25 in November 1971. It was increased again on several occasions, beginning in 1973, but its value in real terms, adjusted for changes in consumer prices, remained low through 1975. (See figure 2.)

\footnotetext{
${ }^{7}$ At least 1965 appears to be the date these two measures were introduced. It is the first year that I found mention of them in the Debates of the Legislative Council.
}

In 1976, as part of the National Pensions Act (which introduced mandatory, contributory pensions), Government increased sharply the size of the non-contributory pension and, even more surprising, abolished the means test. This measure caused the real, price-adjusted value of the pension to increase and, except for a fall in the early 1980s, it has continued to rise ever since. (See figure 2 once again.) It is not known how many elderly were excluded from pensions by the 'income tax' test in effect from 1965, but the apparent coverage of pensions (ratio of pensioners to number of elderly persons) increased from $93 \%$ in mid-1976 to $98 \%$ in mid- 
1977 , so $5 \%$ is a reasonable estimate. ${ }^{8}$

The next major change in non-contributory pensions was announced by the Minister of Finance in his budget speech of 11 October 1983, and implemented the following month. For the first time, higher pensions were provided for the very old, namely Rs 200 for those aged 75-89 and Rs 300 for those aged 90 and over, compared to Rs 174 for younger pensioners. From a reading of the parliamentary debates of 1983 , it is not clear why Government chose to favour the very old in this way. What is clear is that increased pensions for the very old were popular, and easier to finance than a similar increase in generosity toward old age pensioners of all ages.

By 1995, a fourth age group, the over 100, had been created, though this must have been a very small group indeed. For the fiscal year ending June 1996, monthly pensions for the four groups were as follows:

- $\quad$ age 60-74: Rs 675 (USD 38)

- $\quad$ age 75-89 Rs 840 (USD 47)

- $\quad$ age 90-99: Rs 3,900 (USD 220)

- age 100+: Rs 4,000 (USD 226)

In July of 1996, the first two age groups were merged, and remain so today; monthly pensions for the three respective age groups were set at:

- $\quad$ age 60-89: Rs 1,000 (USD 55)

- age 90-99: Rs 3,900 (USD217)

- age 100+: Rs 4,000 (USD 222)

In July of each subsequent year, these pensions

\footnotetext{
${ }^{8}$ There is additional evidence that supports the $5 \%$ estimate for those disqualified by the means test. The Prime Minister, in response to a question from a member of the legislature, stated that the number of old age pensioners who were taxpayers in 1981/82 and 1982/83 was 2650 and 2940 respectively. I do not have statistics on the number of pensioners in those years, but they must have numbered about 62,000 and 66,000 respectively. If these estimates are correct, $4.4 \%$ of old age pensioners paid income tax in those years, which is a figure quite close to the 5\% estimate for 1976/77.
}

were increased by an amount well in excess of price inflation and, most often, greater than the increase in average earnings as well. By July of 1998 (possibly sooner) there existed a supplemental payment for severely disabled pensioners equal to $70 \%$ of the smallest basic pension.

From figure 1 and appendix A, it is clear that pension coverage in Mauritius has been truly universal since 1977. In fact, since 1994 coverage has been more than universal, reaching an estimated 103 to $108 \%$ of the population older than 60 years of age. Some of this apparent over-coverage may reflect under-estimation of the elderly population by the Central Statistical Office. The population census for the year 2000 did enumerate a total of 107,462 persons over the age of 60 , which is more than the 105,234 estimated by the Central Statistical Office, but this still leaves 4,423 of the 111,885 pensioners unaccounted for. Unless the population census is wildly inaccurate, four thousand or so old age pensioners are under-aged or deceased. Mauritius has a reputation for accurate registration of births, so, if there is fraud, it more likely stems from failure to report deaths than from false claims of old age.

For one who has never visited Mauritius, it is difficult to speculate on what role fraud might play in explaining apparent coverage ratios that exceed $100 \%$. Nonetheless, generous pensions at advanced ages are an incentive for adult children or grandchildren to delay reporting the death of an elderly parent or grandparent. Any individual in Mauritius can collect the pension of an elderly person, simply by presenting the pensioner's identity card at a pay point. This is convenient for pensioners, but it does facilitate fraud. In other developing countries, this type of fraud is not unknown. In Namibia, for example, "it was common for pensions to be collected by grandchildren up to ten years after a pensioner was actually deceased." (Schleberger, 2002, p. 14). This activity ended only after authorities began to require the elderly to collect pensions in person, presenting fingerprint identification along with their identity card. Basic pensions in Namibia, like those in Mauritius, are universal 


\section{Figure 3. Ratio of Average Pension to per capita GDP (percentages, 1950-2001)}

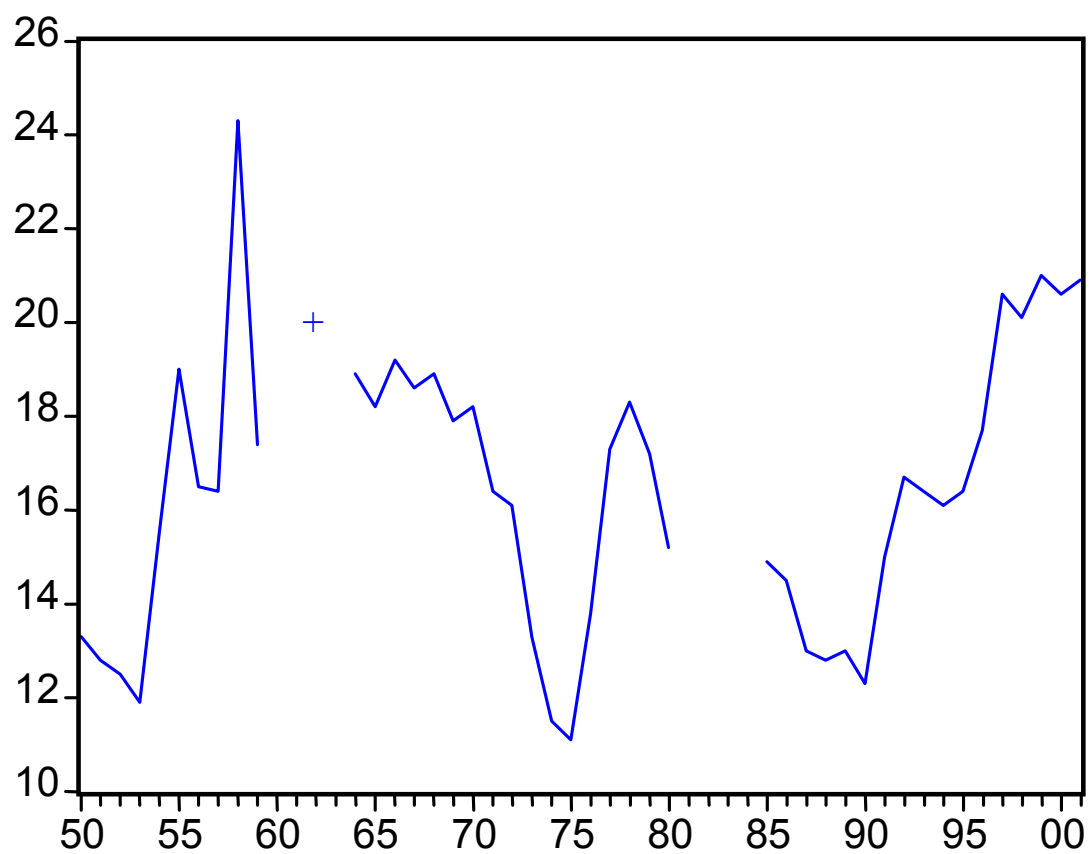

Source: Appendix A.

Note: Pension data missing for 1960, 1961, 1963 and 1981-84.

and non-contributory, but it is worth noting that changing to a means-tested or contributory system would not prevent this type of fraud, except as a by-product of reducing the number of pensioners.

As figure 2 shows, the purchasing power of the old age pension in Mauritius has increased steadily since the mid-1980s, and by 2001 was 2.6 times higher than its previous peak of 1978 . The record of pensions in relation to per capita income, which is a measure of the relative standard of living of those who rely on a basic pension for income, is more mixed. It is true that the pension has tended over half a century to retain its value as a percentage of per capita GDP but, as can be seen in figure 3, there has been enormous fluctuation in this statistic. The ratio of the average pension to per capita GDP statistic increased from about $12 \% 1990$ to $21 \%$ in recent years, but remains below the $24.3 \%$ recorded in 1958 . The lowest ratio was $11.1 \%$, recorded in 1975.

\section{THE COST OF UNIVERSAL PENSIONS IN AN AGEING POPULATION (1970-2040)}

"The worry about ageing is much ado about rather little.... Economists should stop being so dismal. All it will take is a little imagination and courage for most...countries to enjoy their escape from the age-old tyranny of early death."

--- Martin Wolf, writing in the Financial Times, 6 February 2001.

Mauritius has a population that is ageing, in the sense that birth rates have fallen, and people are living longer, so the ratio of the population of working age to the population of pension age, known as the pensioner support ratio, is falling. With these demographics, some question 
whether the country can afford to retain its system of universal pensions, at least at their present level of benefits. The purpose of this section is to argue that such fears, while understandable, are exaggerated. So long as per capita GDP continues to grow (or doesn't fall), there is no cause for alarm. The denominator of per capita GDP, after all, includes both workers and non-workers. If there is a crisis because of demographics despite economic growth, it will be a crisis of politics (distribution), not a crisis of production.

The scenario that is supposed to be so alarming for Mauritius is shown in table 1. All figures are either taken directly from, or calculated from, those reported on pages 8-9 and 20-24 of the Actuarial Review of the Mauritius National Pensions Fund as at 30 June 2000, with some exceptions. The main exceptions are the addition of the year 1970 (for comparison with the past) and the addition of a later retirement age (to see how this affects costs). The actuaries used the demographic projections of the Central Statistical Office, as does table 1 for the projections of population aged 60-64 years. Also, the actuaries include disability and survivors' pensions in their projections. Table 1 ignores these pensions because ageing increases only costs of old age pensions; in fact, there will be fewer young widows and orphans as people live longer and healthier lives.

Assuming everyone begins paid work at age 15 and retires at age 60 , the number of workers per retiree is projected to fall from 7.4 in the year 2000 to 2.5 by the year 2040. (See table 1.) In other words, in less than forty years there will be only 2.5 workers to support each pensioner. Three comments can be made regarding this projection. First, the trend is not a new one: the ratio has fallen since 1970, yet the pension programme is stronger today than it was thirty years ago. Second, it assumes that the population can be divided by age into two distinct groups: workers and non-workers. In reality, many non-workers, such as students, unpaid caregivers and the unemployed are in the 15-59 year age group, and many of those older than 60 continue to pay taxes and work for pay.
Third, 60 as an age for pension eligibility is arbitrary. With increased life expectancy, it should be feasible to phase in a later retirement age, such as 65. If this were done, the pensioner support ratio would fall by the year 2040 only to 3.9 , instead of 2.5. (See table 1 once again.)

The most important defect of the pensioner support ratio, however, is that changes in it do not necessarily correlate with changes in the affordability of old age pensions. To calculate affordability, three statistics are required: per capita GDP, the average pension, and the proportion of pensioners in the overall population of the country. As shown elsewhere (Willmore, 2001), the cost of pensions (as a proportion of GDP) is equal to the proportion of pensioners in the population times the ratio of the pension to per capita GDP.

GDP per capita is a crucial variable; with larger incomes, many things become affordable, including generous pensions for large numbers of retirees. The actuaries (on advice of Government) assume that per capita GDP will increase much more slowly in the future than it has in the past. In the thirty years from 1970 to 2000, per capita GDP increased more than threefold, from 28 to 100 thousand rupees, in constant prices of the year 2000 . In the thirty years to 2030, it is projected to increase by less than 50\%. Nonetheless, real incomes are projected to rise, albeit at a slower pace. Mauritians in the year 2040 are likely to enjoy a higher standard of living than those of the year $2000,76 \%$ higher, on the assumptions the lie behind the figures of table 1 .

For average pension, the actuaries worked with two different projections: (1) pensions indexed to average earnings (assumed to follow per capita GDP) and (2) pensions indexed to consumer prices. In the past, with much fluctuation, basic pensions have adjusted in line with earnings. If we assume this holds for the future, pensions will increase by the same amount as per capita GDP: $76 \%$ by the year 2040 , to an annual pension of 37,000 rupees 
Table 1. Cost of Universal Pensions in Mauritius, 1970-2040.

\begin{tabular}{|c|c|c|c|c|c|c|}
\hline Year & 1970 & 2000 & 2010 & 2020 & 2030 & 2040 \\
\hline GDP (million rupees, constant prices) * & 23369 & 119085 & 152191 & 178151 & 214710 & 258176 \\
\hline Total Population (thousand) & 829 & 1186 & 1292 & 1379 & 1440 & 1465 \\
\hline Children (0-14) & 351 & 305 & 292 & 285 & 280 & 272 \\
\hline Working ages (15-59) & 430 & 776 & 859 & 879 & 870 & 855 \\
\hline Pension age $(60+)$ & 48 & 105 & 140 & 215 & 290 & 338 \\
\hline Pension age $(65+)$ & & & 88 & 141 & 212 & 244 \\
\hline Pensioner support ratio $(\%, 15-59 / 60+)$ & 9.0 & 7.4 & 6.1 & 4.1 & 3.0 & 2.5 \\
\hline Pensioner support ratio $(\%, 15-64 / 65+)$ & & & 10.4 & 6.8 & 4.5 & 3.9 \\
\hline GDP per capita (thousand rupees) * & 28 & 100 & 118 & 129 & 149 & 176 \\
\hline \multicolumn{7}{|l|}{ Average pension (thousand rupees) * } \\
\hline Indexed to earnings & 5 & 21 & 25 & 27 & 31 & 37 \\
\hline Indexed to prices & & & 21 & 21 & 21 & 21 \\
\hline \multicolumn{7}{|c|}{ Pension costs with pension age of 60 ( $\%$ of GDP) ** } \\
\hline Indexed to earnings & 1.1 & 1.9 & 2.3 & 3.3 & 4.2 & 4.8 \\
\hline Indexed to prices & & & 1.9 & 2.5 & 2.8 & 2.8 \\
\hline \multicolumn{7}{|c|}{ Pension costs with pension age of 65 ( $\%$ of GDP) ** } \\
\hline Indexed to earnings & & & 1.4 & 2.1 & 3.1 & 3.5 \\
\hline Indexed to prices & & & 1.2 & 1.7 & 2.1 & 2 \\
\hline
\end{tabular}

${ }^{*}$ All rupee values are in constant prices of the year 2000.

${ }^{* *}$ Assumes 100 per cent coverage of population of pension age. Actual coverage was $90 \%$ in 1970 because

of means testing and $106 \%$ in the year 2000 due to under-estimation of elderly population and payments to deceased pensioners.

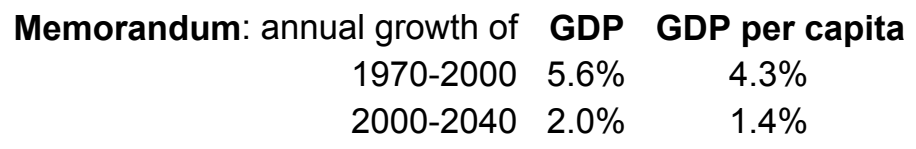

Source: Author's calculations, based on projections of Mauritius Ministry of Social Security, Actuarial Review of the Mauritius National Pensions Fund as at 30 June 2000 (Report by Government Actuary's Department, London, UK, December 2001) and population estimates of the Central Statistical Office of Mauritius. 
(Rs 2,850 a month ${ }^{9}$ ) in prices of the year 2000 . The pension as a proportion of GDP remains the same $(0.21)$, but the proportion of pensioners in the population increases from $(105 / 1186=0.09)$ to $(338 / 1465=0.23)$, so pension costs as a proportion of GDP increase from $(0.21)(0.09)$ to $(0.21)(0.23)$, that is, from $1.9 \%$ to $4.8 \%$. Is this affordable? Well, per capita GDP will be $76 \%$ higher so, even if workers sacrifice $3 \%$ of their income in higher taxes, they will be much better off in the future than they are today, so can easily allow their retired parents and grandparents to share in this prosperity.

If political will and courage are lacking, there are numerous ways to reduce the cost of basic pensions. One way, shown by the actuaries, is to index pensions by prices rather than by earnings. This results in a constant pension of 21,000 rupees (Rs 1,600 a month), in year 2000 prices, for a cost in 2030 and 2040 of $2.8 \%$ of GDP. Another way to reduce costs is to increase from 60 to 65 the qualifying age for a pension. This calculation was not shown by the actuaries, but is shown in table 1 . With this option, pension costs increase to $3.5 \%$ of GDP when indexed to earnings, and to $2 \%$ of GDP when indexed to prices. A third way to reduce costs is to subject applicants to a means test rather than grant old age pensions on a universal basis. This type of cost-cutting measure is examined in some detail in the next section of the paper.

In conclusion, the universal pensions of Mauritius are affordable, even with no change in the qualifying age for an old age pension, and even if pensions increase with per capita GDP to accompany changes in the standard of living of the country. If the qualifying age were to increase from 60 years to 65 , which could be justified because of increased life expectancy, the pensions would become even more affordable. It comes down to political will, of collectively deciding whether universal pensions represent good value for taxpayers' money.

\footnotetext{
${ }^{9}$ Division of 37,000 is by 13 rather than 12 , allowing for a ' $13^{\text {th }}$ month' bonus.
}

\section{UNIVERSAL PENSIONS VERSUS MEANS-TESTED PENSIONS}

Policymakers in Mauritius, from the very beginning, sought to reduce the fiscal cost of old age pensions by subjecting applicants to a test of individual income or, if married, to a test of the combined income of the applicant and his or her spouse. They succeeded in reducing the number of old age pensioners by about 20 or 25 per cent compared to what might have been expected with a universal programme. Some members of the Legislative Council wanted to cut costs even more with a harsher means test, one that takes into account not only income of a spouse, but also potential alimony from sons or daughters. Government, they argued, should force children to care for their aged parents; it should provide a pension to someone in poverty only if the person has no adult children, or if those children also live in poverty. A motion to tighten the means test in this way was introduced in course of debate of the Old Age Pensions (Amendment) Bill, and narrowly defeated by a vote of 13 to 12, with two abstentions (Debates, 30 June 1953).

As Mauritius gained experience with noncontributory pensions, calls to tighten rules of eligibility subsided, and discontent with means testing grew. In 1958, Government abolished means tests and began to award old age pensions to all who qualified by age, subject only to a residency requirement. Mauritian policymakers learned that even though means tests promise great benefits by targeting benefits, they also have social costs that offset their budgetary appeal.

Amartya Sen (1995, pp. 12-13), in a wellknown essay on "The Political Economy of Targeting", discusses four major social costs of means tests:

- Disutility and stigma

- Informational distortion

- Incentive distortion

- Administrative and invasive losses 
Mauritius suffered all but the first of these costs. Stigma never arose because the overwhelming majority of the elderly population qualified for a pension. Pensioners might become stigmatised as paupers had Government tightened the test to take into account income of their adult children, but this did not happen.

Informational distortion inevitably accompanies means testing because an applicant communicates information to Government in "a system that rewards cheating and penalizes honesty" (Sen, 1995, p. 12). Honest citizens in Mauritius who reported their earnings were shocked to see their pensions reduced by the full amount. They quickly learned to hide their true income. In the words of one member of the Legislative Council, it became "difficult to assess the true position of those poor people and furthermore it does not profit the Government to such a large amount of money" (Debates, 4 December 1951).

Even if applicants were to provide honest and complete information to Government, the existence of a means test discourages the elderly from working and penalizes those who to save for their own old age. This is the "incentive distortion" highlighted by Amartya Sen. Legislators in Mauritius became aware of this very early. In the debate over a bill to relax the means test by increasing the amount of allowable income (Debates, 4 December 1951), one member of the legislature stated "I do not think it is just that Government should think that a person who is allowed a pension of Rs 15 per month should not be encouraged to work if he or she can work." Another complained "the one who has made savings through sacrifices seems to be penalized as compared with the one who has been spending all his wages during his working life time."

A major complaint against the means test was the power that it gives bureaucrats, and the corruption that sometimes accompanies this power. A government minister explained that this was a key reason that Government decided to table legislation in 1958 to abolish the means test:

"[We] know that if an unfortunate person applies for old age pension and does not have any support, it would take months ... [to] obtain the old age pension. I can very well understand why certain elements in the country are against the doing away of the means test. Once this is got rid of, every person who is entitled to receive old age pension would be able to apply for it and, as a matter of law, as a matter of right, will be entitled to it. It will not be a question of whether one Member of the House or some of his friends happen to be persona grata with certain officers... This is one way in which up to now political power has been obtained in certain quarters in this country. This is a fact, ... and this is one of the things which this Government has decided to stop.” (Mr. Rault, Debates, 1 April 1958)

When an applicant has right to a pension simply by submitting proof of age, the government official has little power. When an official is asked to certify the income of an applicant, he obtains power, which provides opportunity for corruption and for abusive invasion of privacy. A backbencher noted this with particular clarity, in the same session of the legislature:

"[T]he abolition of the means test will help...by not giving the opportunity to the [public assistance] officers to do the things they are now doing: long process of enquiries, asking information from the neighbours as to whether So and So is working, whether So and So is the lessee of so many acres of land or whether So and So is maidservant at Mr. So and So's place. At least the proof that the person has reached the qualifying age will put the officer in an obligation to give that person his assistance and nothing more. And if there is not other reason, for this single reason, I am going to vote for this Bill." (Mr. Boolell, Debates, 1 April 1958)

The mild means test that was in effect from around 1965 through 1976 avoided these 
administrative and invasive costs because the test was simple: if you file and pay income tax, you do not qualify for an old age pension. This rule gave no discretionary power to bureaucrats, and was not intrusive. Nor did it stigmatise pensioners, for the vast majority of the elderly in Mauritius do not file income tax. Nonetheless, the test did not avoid the other two social costs: informational distortion and incentive distortion. It provided citizens with yet another reason to distort information, to hide their income, to avoid filing an income tax return. Those who filed a return lost their entire pension, equivalent to a tax of at least $100 \%$ on the pension, even higher in the case of incomes that were only borderline taxable, since the old age pension itself was not taxable. For some, this was a powerful incentive to work very little after reaching age 60 , and a disincentive for younger workers to save for their own old age.

The 'income tax' test could have been a good one, with a slight modification. Instead of recovering the entire pension from those with any taxable income, Government should have imposed a surcharge on income of pensioners at a modest rate, one which would not destroy incentives to work and save, and would apply only until the net old age pension becomes zero. This type of "claw back" was applied for many years in New Zealand, a country that, like Mauritius, has a tradition of non-contributory pensions. The surcharge in New Zealand functioned well, though it was removed in 1998 in order to restore universality (St. John and Willmore, 2002).

The functioning of a surcharge can be made clear with an example, using the basic pension in Mauritius, which in the current fiscal year amounts to Rs 22,100 a year and is fully taxable. The first Rs 25,000 of taxable income is subject to tax at the rate of $15 \%$. Additional income is taxed at $25 \%$, so even the wealthiest person retains a pension of Rs 16,575, net of tax. Suppose, now, that pensioners are charged a surtax of $20 \%$, up to the point where their entire pension has been 'clawed back'. In this example, our pensioner would pay a $20 \%$ surtax on her first Rs 110,500 of taxable income, which would mean a total tax at the rate of $35 \%$ on the first Rs 25,000 of taxable income, $45 \%$ on the next Rs 85,500 of income, and $25 \%$ (without surcharge) on all additional income. For those with larger pensions, such as persons over the age of 90 , the surcharge would apply, with the same principle, to a larger amount of taxable income.

Should Mauritius choose to restore a means test for basic pensions, careful consideration should be given to recovering pensions from the wealthy with a surcharge on their taxable income, at a moderate rates. This type of income test avoids or minimizes all four social costs associated with means tests: stigma, distorted information, distorted incentives and administrative losses. ${ }^{10}$

\section{CONTRIBUTORY, INCOME- RELATED PENSIONS (FROM 1978)}

"The non-contributory pension scheme should continue to exist side by side with this contributory scheme, the former declining as the latter develops. In due course it would be possible to reintroduce a [tighter] means test as part of the non-contributory scheme."

-- A.E. Goddard, Report to the Government of Mauritius on the Planning of Social Security (International Labour Office, Geneva, 1970), p. 53.

Government's long-awaited contributory pension scheme was approved by the National Pensions Act of 1976, but began to operate only in July of 1978. Contrary to the desires of many proponents (including the ILO expert quoted above), the new scheme does not replace noncontributory pensions, even for the wealthy;

\footnotetext{
${ }^{10}$ I owe this point to Susan St. John, who was able to convince me, a stubborn foe of means tests, that the New Zealand system of recovery of pensions from the wealthy via surcharges on their income was a good idea, as it introduced some progressivity, at least for elderly taxpayers, into what had become essentially a flat rate of income tax.
} 
rather, it tops up basic pensions with contributory pensions designed to replace onethird of covered earnings. ${ }^{11}$ Participation is mandatory for workers older than 18 years of age, with the exception of employees with very low earnings ${ }^{12}$, the self-employed, and public sector employees. Self-employed workers and the unemployed are offered incentives (2/3 contribution for the same benefit) to participate voluntarily, but few do. Workers in the public sector have no need to participate because Government meets their retirement income needs with generous pensions that are incomerelated and non-contributory. ${ }^{13}$ As a result, the scheme covers only half the labour force (some 280,000 persons) and not every participant contributes on a regular basis.

Participants in the new pension scheme are required to contribute - up to a ceiling ${ }^{14}$ - a fixed proportion of their salary, set at the rate of $9 \%$ (6\% from the employer and 3\% from the employee). Workers in large sugar estates contribute $50 \%$ more (via their employers), and receive correspondingly greater benefits. In exchange for contributions, workers receive "pension points" that are re-valued periodically

\footnotetext{
${ }^{11}$ Contributors to the National Pensions Scheme benefit also from life and disability insurance during their working lives; this supplements basic widows', orphans' and disability pensions awarded to residents less than 60 years of age under the non-contributory system. Life and disability benefits are ignored in this paper in order to concentrate on old age pensions.

12 For the fiscal year ending June 2000, mandatory contributions were triggered by monthly wages of Rs 800 (USD 30).

${ }^{13}$ Under an occupational scheme that dates from 1859, public servants after $331 / 3$ years of service receive twothirds of their final pay as a pension, and can retire as early as age 50, but never later than age 60 . For pension purposes, the public sector includes employees of 'parastatals', such as teachers in government-aided private schools. Pensions of civil servants are not only generous; they are paid on a pay-as-you-go basis, so cause problems for public finances as the population ages. (See World Bank, 1995, pp. 46-51).

${ }^{14}$ The ceiling for contributions in the year ending June 2000 was a monthly salary of Rs 5,535 (USD 220).
}

at the discretion of the Minister of Social Security. Upon reaching the normal retirement age of 60 years, the value of the accumulated pension points can be exchanged for a lifetime pension at a rate determined by Government. Since July 1988, this rate has been fixed at 11:1. Pension points valued, for example, at 110,000 rupees can be transformed into a monthly pension of 833 rupees (Rs 10,000 a year). ${ }^{15}$

There is no formal indexation, but Government promised that it would revalue pension points in accordance with changes in average earnings, and created the expectation that pensions in payment would benefit from a similar adjustment. Government stated this explicitly in a White Paper published in April of 1976:

"The level of earnings on which pensions are calculated will be adjusted for changes in the average level of earnings up to retirement. This process of 'dynamising' past earnings will ensure that contributions paid into the new National Pension Scheme keep their value right up to pension age. Once pensions are in payment the Government will review their level in the light of changes in the cost of living and in living standards." (Mauritius, 1976, p. 2.)

This did not happen. From the beginning, the Minister of Social Security adjusted pension points and pensions in payment each year or two roughly according to changes in consumer prices, not to changes in average wages. Prices have increased less than wages; so pensions are smaller than promised.

This de facto price indexation need not continue in the future. Indeed, the recent actuarial review (Mauritius Ministry of Social Security, 2001) assumes that the value of

\footnotetext{
15 The division of 10,000 is by 12 , because there is no ' $13^{\text {th }}$ month' bonus for contributory pensions. The rate of 11:1 to exchange pension points for a pension is given in the actuaries report (Mauritius Ministry of Social Security, 2001). The source does not report the rate or rates in effect prior to July 1988.
} 
pension points increase with average wages over the next forty years, while the value of pensions in payment continue to increase at a slower pace, in tandem with consumer prices. There is uncertainty how, or even whether, contributions and benefits will be adjusted as prices and wages rise, which gives present and future pensioners cause for concern.

The contributory pension scheme in Mauritius is an early example of what has come to be known as a "notional defined contribution" system. It is "defined contribution" because benefits depend strictly on contributions, not on final or even the average lifetime income of participants. It is "notional" because participants do not purchase portfolios of stocks and bonds, or shares in an investment fund; instead, they receive points, the values of which do not depend in any way on how, where, or whether their contributions are invested.

When a contributory system of pensions is set up, at first there are many contributors and few beneficiaries, so there is a lot of revenue and little expenditure. Pensioners steadily increase in number, but the first to reach pension age have a short history of contributions, so are eligible for very small pensions indeed. The surplus of receipts over expenditures continues until the scheme matures, and expenditures equal receipts, which might be forty or fifty years. This cash surplus is one of the great attractions of a contributory scheme. Non-contributory pensions make demands on the public purse. Contributory schemes make no financial demands on government, and can even help out by lending funds to the government treasury.

Policymakers everywhere face the decision of what to do with surpluses that a pre-funded pension scheme generates. In Mauritius, they decided "to build up a fund for national development" (Smith and Lynes, 1976, p.1) and named it the National Pension Fund. At first the Fund invested only in government paper. This drew criticism from the political opposition, which complained that Government was using "workers' contributions to guarantee the wastage and dissipation of public funds by Government"
(Debates, 22 April 1981). Just as beauty is in the eye of the beholder, one person's national development is another's government waste. Government reacted to this criticism by instructing the Fund to finance a low-interest Housing Loan Scheme for the benefit of contributors. Eventually, the Fund began also to purchase shares and debentures of private companies. By 30 June 2002, nearly $10 \%$ of the Fund's total portfolio of Rs 22,422 million (USD 747 million), was invested in housing loans and another $10 \%$ in shares and debentures of private companies. The remaining $80 \%$ was held almost entirely in government paper and bank deposits. (Mauritius Ministry of Social Security, 2002.)

With most of its investments in treasury bills and government bonds, the main effect of the National Pension Fund has been to ease the budget constraint of Government. Government has been able to spend more, without the necessity of collecting additional taxes, because it has access to the contributions of workers who are forced to save for their own retirement. Revenue can be spent in many ways, and we will never know what the spending (or the tax revenue) of Government might have been without the pension fund. But it is not unreasonable to assume that at least part of the spending was to improve the lot of pensioners. That was, after all, the stated purpose of the National Pensions Act of 1976. Was it coincidence that Government decided that very year to increase the generosity of the basic, noncontributory pension? If not, then it is possible that the contributory pension scheme, far from replacing the non-contributory scheme, gave it new life by easing the budget constraint of Government.

Many workers who joined the new contributory pension scheme were unable, because of their age, to accumulate many credits or points before retiring on a tiny pension. Government has set up two programmes to aid this first generation of contributors to the National Pension Fund. Both programmes provide subsidies for retirement pensions; one is 
financed by general government revenue, the other directly by surpluses of the Fund itself.

The first programme guarantees a minimum pension for every participant, regardless of her history of contributions. Government has kept the purchasing power of this minimum pension constant by adjusting it each year for consumer price inflation. In the fiscal year ending June 2000, the minimum contributory pension was Rs 219 (USD 9) a month. Though not a large sum, it is a windfall for someone who may have contributed only a few months to the National Pension Fund before receiving this pension for life. The difference between the guaranteed pension and the amount that would otherwise have been payable is paid by Government out of general tax revenue. For the fiscal year that ended June 2000, the cost to Government of the minimum pension guarantee was 22 million rupees, an amount equal to $11.5 \%$ of the total expenditure on all 31,400 contributory retirement pensions in payment, but only $1 \%$ of the cost of the nearly 112,000 non-contributory pensions in payment that year (Mauritius Ministry of Social Security, 2001, table 11. p. 26 and table D7, p. 53). ${ }^{16}$

The second programme is more costly, and is financed, not out general government revenue, but by the National Pension Fund itself. Because the Fund provides a subsidy to the first generation of participants, its investment portfolio is smaller. This could be viewed as unimportant, a mere accounting device. Government could pay for this programme out of general revenue, just as it pays for the cost of guaranteed minimum pensions, and loans from the fund (increased holdings of government paper) could finance the expenditure. This would be an alternative accounting device, for the same end. The accounting is important,

\footnotetext{
16 In fiscal year 1999/2000, contributory pensions in payment averaged Rs 510 (USD 20) per month. Detailed statistics are not available, but the median (mid-point of the distribution) is likely to be even smaller, with a significant percentage receiving only the minimum pension. The average non-contributory old age pension in payment that same year was more than three times as large, Rs 1,645 per month.
}

however, for it influences very much who bears the burden of this subsidy, contributors to the Fund or taxpayers in general.

The subsidy financed by the Fund is given to all participants who were aged 20 to 59 years in July of 1978. Workers who were older than 40 years of age in July 1978 receive double the normal number of pension points for their contributions, thus a pension twice as large as they would be entitled to under normal rules. Workers younger than 40 , but at least 20 years old in July 1978 receive sufficient bonus to qualify for the pension they would have received had they contributed at the same rate for a full 40 years. The formula for bonus points for this age group is $(\mathrm{X}-20) /(60-\mathrm{X})$, where $\mathrm{X}$ is age in July 1978, provided it is between 20 and 40. A worker who was 35 years old in 1978, for example, is credited with $15 / 25(60 \%)$ more pension points, hence collects a $60 \%$ larger pension than would normally be payable, on retirement in the year 2003. A worker who was 21 years old when the scheme commenced receives a subsidy of only $1 / 39$, little more than a $2.5 \%$ increase in the pension that is payable beginning in the year 2117 .

Younger workers, those born after July 1958, are unlikely to benefit from a pension guarantee and accumulate only the normal amount of points for their contributions, without a subsidy. They can expect only a normal pension on retirement. Or, can they? If one takes as a basis for 'normal' pensions, revaluation of pension points each year by changes in average earnings, then pensions that the younger generation will receive already are smaller than those promised by Government. They may have to increase their rate of contribution and accept even smaller pensions, for the actuaries (Mauritius Ministry of Social Security, 2001, p. 28) reported that the National Pension Fund is not in actuarial balance. Required for full advance funding, according to their calculations, is an increase in the contribution rate from $9 \%$ to about $10 \%$ of covered income, combined with an increase in the rate of exchange of pension points from 11:1 to 12:1. These changes are necessary only because Government insists that 
all benefits be pre-funded, and then only because it charges the Fund for subsidies given to the first generation of participants. If all subsidies were paid from general government revenue, as the minimum pension guarantee is, the Fund would show an actuarial surplus rather than a deficit. Accounting rules are important, for they frame policy and determine who, if anyone, in the next generation pays for subsidies provided to the first generation of workers to retire with contributory pensions. ${ }^{17}$

\section{THE ATTRACTION OF CONTRIBUTORY PENSIONS}

Once non-contributory, basic pensions ensure that no elderly person suffers absolute poverty, why should government compel citizens to save for their own retirement? Tastes, preferences and circumstances differ from person to person, so why not leave retirement savings decisions to individual choice? Governments rarely abstain from forcing their citizens to save for their old age, and they are not behaving capriciously. They are attracted to contributory pensions as a tool to advance any or all of the following goals:

- Increase national saving;

- Avoid redistribution of income and wealth;

- Ensure that living standards of workers do not fall in retirement;

- Build up a fund for government use.

Both the first, and especially the second goal require contributory pensions to replace universal, basic pensions. The other two goals can easily accommodate a contributory pension scheme without cutting entitlements to noncontributory, basic pensions.

\footnotetext{
17 Recall the 8 April 1958 promise of a government minister "There will be of course no burden placed on the coming generations as soon as this contributory scheme is introduced." (See above, section 2, pp. 3-4.)
}

(a) Increase national saving

At various times in Mauritius, proponents of contributory pensions have stressed the need for each person to save for his or her own retirement, in order to relieve future generations from this burden. As stated, however, the argument is incomplete, for it fails to explain how personal savings are to be transformed into national savings.

Consider a simple thought experiment, using a framework known as an overlapping generation model. Imagine a country whose 300 residents live only three years; they are successively young, middle-aged, and old. The population is stationary, so births equal deaths and generations are always of equal size (100). There is no inflation, and the interest rate is zero. The young and the middle-aged pay taxes to finance a non-contributory pension of 2 rupees given to each of the old. The annual cost of universal pensions (transfer to the old) is 200 rupees, financed on a pay-as-you-go basis by a tax of one rupee on each of the 200 non-old residents of the country. Initially (in year 0 of the table below) there are no contributory pensions, and there is no pension fund. The young and the middle-aged bear the burden of paying for the pensions of the old.

\section{Table 2. Hypothetical Overlapping Generations Model}

\begin{tabular}{|c|c|c|c|c|c|c|}
\hline \multirow[b]{2}{*}{ Yr } & \multirow[b]{2}{*}{ Young } & \multirow{2}{*}{$\begin{array}{l}\text { Middle- } \\
\text { aged }\end{array}$} & \multirow[b]{2}{*}{ Old } & \multicolumn{2}{|c|}{ Pension fund } & \multirow{2}{*}{$\begin{array}{l}\text { Transfers } \\
\text { to old }\end{array}$} \\
\hline & & & & Deposit & Withdrawal & \\
\hline 0 & - Rs 100 & - Rs 100 & + Rs 200 & 0 & 0 & Rs 200 \\
\hline 1 & - Rs 100 & - Rs 100 & + Rs 200 & Rs 200 & 0 & Rs 200 \\
\hline 2 & - Rs 100 & - Rs 100 & + Rs 200 & Rs 200 & Rs 100 & Rs 100 \\
\hline 3 & - Rs 100 & - Rs 100 & + Rs 200 & Rs 200 & Rs 200 & 0 \\
\hline 4 & - Rs 100 & - Rs 100 & $+\operatorname{Rs} 200$ & Rs 200 & Rs 200 & 0 \\
\hline
\end{tabular}

Note: Illustrative numbers. A non-contributory pension scheme becomes contributory and pre-funding begins in year 1. Build-up of the fund is complete in year 2 . See text for details.

In year 1 Government introduces a contributory pension scheme, and allows each young and middle-aged person to save one rupee for old age, rather than pay it in taxes. In year 1, 200 deposit a total of 200 rupees into the pension fund; so personal saving increases by Rs 
200. The old in year 1 have not saved for their own pensions (they were paying taxes instead), so have to rely on government. Government has no tax revenue in year 1 , but can borrow Rs 200 from the pension fund to finance pensions of the old that year. In sum, in year 1, the year the contributory pension scheme is inaugurated, personal saving increases by Rs200, but government debt increases by the same amount, so national saving is unchanged.

The following year (year 2) another 200 rupees are deposited, but the generation that was middle-aged in year 1 is now old, and withdraws its savings, so net personal saving is Rs 100 . Those who are old in year 2 were "born" in year 0 , so were able to save for only one year, enough for a pension of only 1 rupee. To provide them with a full pension, government must double their contributory pensions, to 2 rupees. This requires Rs 100, which government again borrows from the pension fund.

The balance of the pension fund in year 2 is Rs 300, all of which is held as government debt. From year 3, deposits are equal to withdrawals, so net personal saving is zero, and the balance in the fund remains at Rs 300, as does government debt, since every old person has now saved for her own retirement. Personal savings in this economy have increased by Rs 300 , national savings are unchanged, and government debt has increased by Rs 300 . The only effect the introduction of a contributory scheme had was to transform implicit government debt into explicit debt, held as the investment portfolio of the pension fund. The explicit debt is the subsidy given to pensioners in year 1 and year 2, during the build-up phase of the pension fund.

Why is the implicit debt of the pay-as-yougo, non-contributory system equal to Rs 300 ? Why not Rs 400 or some even larger sum? In year 0 there are 200 residents who expect to receive, from government, a pension of 2 rupees when they become old, and 2 times 200 is 400, not 300 . Or, why is the implicit pension debt, before the system is reformed, not infinite? After all, an infinite number of unborn generations can expect to receive a non-contributory, universal pension when they become old.

There is a reason why the implicit debt is Rs 300 rather than Rs 400 or an infinite sum. It is because the middle-aged in each year have paid taxes in two years, so have acquired the right to a full pension, whereas the young have paid taxes only in one year, so have acquired rights to only half a pension. The unborn have not paid any taxes, so have not acquired any entitlement. The cost of a full pension for 100 persons is 200 rupees, and the cost of half a pension for the same number is 100 rupees. The figure of Rs 300 is the sum of these two entitlements.

We have seen in this illustration that personal saving has no effect whatsoever on national saving. This happens because government borrows all surpluses from the pension fund to subsidize pensioners who are too old to save enough for a full pension. The outcome would be quite different if government were to finance the subsidies by taxing rather than borrowing. In table 2, the 200 residents who are not yet old would be subject in year 1 to a tax of one rupee each in addition to the compulsory saving of one rupee, and in year 2 the tax would amount to one-half a rupee. This increase in national savings comes about because of an increase in taxes, and does not require advance funding of pensions; fiscal austerity alone can produce the same result. Pension reform, though, is sometimes appealed to as a way to make tax increases more acceptable to the electorate.

We have assumed, for simplicity, that contributory pensions are set equal to the old non-contributory pensions. Government can force citizens to save additional amounts, for example by setting contributions proportional to income. If this generates surpluses in the pension fund greater than the amount required to subsidize the first two generations of pensioners, the result could be increased national saving, even without increases in taxes. On the other hand, national saving could fall if government borrows from the pension fund to finance current consumption and contributors adjust 
their own portfolios by reducing other saving. Anything can happen to national saving in theory; what actually happens must be measured, which turns out to be quite a difficult task. Barr (2000, p. 14) summarizes "a large, complex and controversial literature" in the following way: "The magnitude of the impact of funding on growth is controversial. Though there is some empirical evidence that funding contributes to higher savings in the United States, there is no robust evidence of a similar effect elsewhere."

\section{(b) Avoid redistribution of income and wealth}

Avoidance of income redistribution was a major force behind contributory pensions from the beginning in Mauritius, and was central to the Report of the Social Insurance Committee in 1941. The aim is to spare the taxpayer by forcing each worker to save for his or her own retirement, i.e. to substitute workers' contributions for the taxes paid disproportionately by the wealthy. To pursue this goal, a pension plan will ideally exclude those who are not poor, since they make no demands on Government in their old age, and will mandate flat contributions in return for flat benefits at a subsistence level. Dr. Millien, the only member of the Social Insurance Committee to express a dissenting view, saw this clearly. His analysis was correct. The scheme proposed in 1941, and the similar one proposed by a Committee of Ministers in 1957, would have reduced the income and living standards of the working poor. In the thought experiment of the previous subsection, we abstracted from this issue with the simplifying assumption of head taxes that do not vary by person, except for the old, who are exempt.

(c) Ensure that living standards of workers do not fall in retirement

This goal is paternalistic because it represents an attempt to protect not taxpayers, but workers themselves. The belief is that at least some workers are so short sighted that they would consume too much of their wages and save too little for retirement if they were allowed to choose their own pattern of lifetime consumption. The implicit assumption is that government knows best: without compulsion, individuals make mistakes that they later come to regret. So government forces each worker to save enough to avoid a drastic fall in his or her standard of living in retirement.

Paternalism underlies the recommendations of Titmuss and Smith (1961, pp. 107-111) and, to a lesser extent (because of Governmentimposed constraints), those of Smith and Lynes (1976). With paternalism as the underlying motivation, it is important that pensions be adequate to allow a retiree to maintain the standard of living to which he or she has become accustomed, even though this standard is much higher than minimum standards of the community. Pre-funding is of no consequence; the scheme might be financed on a pay-as-yougo basis, with each generation of workers paying for the pensions of the previous generation. In essence, the social planner observes that citizens face a drop in their income on retirement, so forces them to save more (reduce consumption) during their working years in order to enjoy more consumption in retirement.

The paternalistic motive for contributory pensions is strikingly evident in the following passage of the Titmuss Report (1961, p. 108):

"[T]here are various groups of employed persons who have become accustomed to a somewhat better standard of living but who, in their old age, have to rely on the present basic pension. Many no doubt get generous help from their families but this pension alone is inadequate to maintain a reasonable standard.... These workers are among the most deserving sections of the community; teachers in private schools, clerks, skilled workers, and certain categories of employees of hotels, shops, and various industries."

The Report clearly states (p. 111) that the objective should be "to maintain the whole social insurance scheme broadly on a 'pay-as-you-go' 
basis, bearing in mind the need to build up ... a moderate working balance in the Fund." Titmuss and Smith wanted current contributions to be used to aid current pensioners rather than build up national savings or finance other government expenditure.

\section{(d) Build up a fund for government use}

The fourth and final rationale for compelling workers to participate in a contributory scheme is to build up a fund that can be used for purposes to be decided by government. Smith and Lynes (1976, p. 22), in the report commissioned by the Government of Mauritius, explicitly state that it "has been the Government's wish to build up a fund to promote national development." We have seen that "national development" essentially means purchase by the pension fund of government bonds, allowing government to decrease taxes or increase its spending. Some of this increased spending was on basic pensions, by abolishing the means test and sharply increasing their value. It is interesting to note that in 1958, the other year in which the generosity of the basic pension peaked, Government also announced its intention of introducing a contributory pension scheme within two years. The expected inflow of cash from contributions may have played a role in each of these events, even if expectations were never fulfilled in the case of 1958.

\section{CONCLUSION}

The World Bank, in its highly regarded 1994 Report, Averting the Old Age Crisis, praised schemes that provide benefits

"to everyone of pensionable age, regardless of income, wealth or employment history, as in New Zealand and the basic pensions paid by the Nordic countries. Administratively, this is the simplest structure, with the lowest transaction costs, for the public pillar-an important advantage in developing countries with limited institutional capacities and incomplete record-keeping systems. It avoids the disincentive to work and save inherent in means-tested plans. Its universal coverage helps ensure that the poverty reduction objectives are met, provides a basic income for all old people" (p. 240).

Mauritius demonstrates clearly that basic pensions for all are not only theoretically desirable; they are also affordable and politically feasible in a developing country.

Mauritius ended up with a system of universal old age pensions by accident, not by design. Basic, flat pensions from the very beginning in 1950 were regarded as temporary, something to take care of the needs of the aged until the day a contributory, incomes-related system of pensions could be put into place. Nonetheless, once the non-contributory system was in place, it proved to be both popular and durable. The long-awaited arrival of contributory pensions in 1978 has been followed not with a replacement, but rather the strengthening of the basic, flat pensions for all elderly residents in the country.

Despite the obvious advantages of simple, universal old age pensions, there are very few examples in the developing world. Namibia and Botswana operate systems of universal pensions, and South Africa's basic pensions are nearly universal (Willmore, 2001), but these examples, along with Mauritius, seem to be unique. It is thus unusual that the Government of Nepal, on of the least developed countries in the world, introduced in 1995 a universal pension of Rs 100 per month (approximately $10 \%$ of per capita GDP) for all persons over the age of 75 , and for "helpless widows" 60 to 74 years of age. The value of the pension was subsequently eroded by inflation, but in fiscal year 1999/2000 the Government increased it to Rs 150 per month, equivalent to almost 11\% of per capita GDP. In 1999/2000, a total of 171,322 persons over the age of 75 benefited from pensions, along with 188,557 "helpless widows", for a total of 359,879 pensioners, $1.6 \%$ of the population. ${ }^{18}$ The total

\footnotetext{
${ }^{18}$ If the estimates of the UN Population Division (2000 Revision) are accurate, the 'universal' pension was delivered in 1999 to only $60 \%$ of the population older than
} 
cost of these pensions, as a share of GDP, was thus a very modest $0.0159 * 0.108$ or $0.17 \%$ of GDP.

The fact that Nepal started with a universal pension at age 75 seems a good idea. Those of such an advanced age are in greatest need, and the pension is more affordable than it would be if younger persons were included. Over time, as the country develops, it should be possible to provide pensions also to those of younger ages. In this, too, Mauritius provides lessons, by differentiating its old age pensions by age group. The pension for those 75 years of age and older could be left larger than that, say, for pensioners aged 60-74, allowing for a gradual withdrawal from paid labour that is typical in poor countries.

Mauritius has had two experiences with means tests. The first, lasting from 1950 until 1958 , excluded the wealthiest 20 to $25 \%$ of the elderly. The second, lasting from around 1965 through 1976 excluded only those liable for income tax, no more than $5 \%$ of the elderly population. These tests produced fiscal savings, but they also sent distorted signals to workers. Both tests discouraged low-income workers from saving for their old age and from continuing to work, even on a part-time basis, beyond normal retirement age. The first test was the more costly, and more unpopular, of the two because it was costly to administer and led to invasion of privacy. If, for some reason, it is necessary to deny basic pensions to wealthier members of society, it is far better to do this through the existing tax system. Mauritius did this by recovering, in effect, the entire pension from anyone who filed an income tax return. It would have been better to 'claw back' the pension gradually, by collecting a surcharge on a pensioner's taxable income, as was done until recently in New Zealand (St. John and Willmore, 2001). If the rate of surcharge plus normal income tax is not confiscatory, it will

age 75. It is not known how many women aged 60-74 are widowed, nor if a means test is applied, but "helpless widows" comprise $34 \%$ of the female population of that age group. have little adverse effect on incentives for work and for saving. A portion of the pension can be recovered from pensioners who continue to work or have investment income simply by making the non-contributory pension taxable as ordinary income. This is done in both Mauritius and New Zealand, with excellent results. 


\section{References}

Barr, Nicholas (2000). "Reforming pensions: myths, truths, and policy choices," IMF Working Paper WP/00/139 (August).

Goddard, A.E. (1970). Report to the Government of Mauritius on the Planning of Social Security (International Labour Office, Geneva).

Heston, Alan, Robert Summers and Bettina Aten (2002). Penn World Table Version 6.1, Center for International Comparisons at the University of Pennsylvania (CICUP), October. http://pwt.econ.upenn.edu/

Manandhar, Narayan (circa 1999). Social Security in Nepal. On the web at http://www.labournepal.org/labourissues/soci alsecurityinnepal.html. Accessed 13 February 2003.

Mauritius (1948). Social Insurance Schemes in Mauritius. Correspondence Exchanged between the Government of Mauritius and the Colonial Office (Government Printer, Port Louis, Mauritius).

Mauritius (1976). The National Pension Scheme (Port Louis, Mauritius, April).

Mauritius. Central Statistical Office (1999). Population Ageing and the Elderly in Mauritius (Port Louis, Mauritius, July).

Mauritius. Legislative Council. Debates (Port Louis, Mauritius, various issues, 19501988).

Mauritius. Ministry of Social Security (2001). Actuarial Review of the Mauritius National Pensions Fund as at 30 June 2000. Report by Government Actuary's Department (London, UK, December). http://ncb.intnet.mu/ssns/ministry/download /npfdec.pdf

Mauritius. Ministry of Social Security (2002).

National Pension Fund. http://ncb.intnet.mu/ssns/ministry/npfund. html

St. John, Susan and Larry Willmore (2001). "Two legs are better than three: New Zealand as a model for old age pensions," World Development 29:8 (August), pp. 1291-1305. An earlier version was presented to the ISSA research conference in Helsinki, Finland, 25-27 September 2000.

Schleberger, Eckard (2002). Namibia's Universal Pension Scheme: Trends and Challenges (ESS Paper No. 6, International Labour Office).

Sen, Amartya (1995). "The political economy of targeting," in Public Spending and the Poor, edited by D. van de Walle and K. Nead (Johns Hopkins University Press, Baltimore, Maryland), pp. 11-24.

Smith, Brian Abel- and Tony Lynes (1976), Report on a National Pension Scheme for Mauritius (Government Printer, Port Louis, Mauritius)

Subramanian, Arvind and Devesh Roy (2001). "Who can explain the Mauritian miracle: Meade, Romer, Sachs or Rodrik?" IMF Working Paper WP/01/116 (August).

Titmuss, Richard M. and Brian Abel-Smith, assisted by Tony Lynes (1961). Social policies and population growth in Mauritius: report to the Governor of Mauritius (Methuen and Co., London). Widely known as the 'Titmuss Report' and first published by authority of the Mauritius Legislative Council as Sessional Paper No. 6 of 1960.

UNDP (2002). Human Development Report 2002: Deepening Democracy in a Fragmented World (Oxford University Press, New York).

Willmore, Larry (2001). "Universal pensions in low income countries," Initiative for Policy Dialogue Discussion Paper IPD-01-05 (September). A revised and expanded version (November 2001) is posted at http://www.geocities.com/larrywillmore.

World Bank (1994). Averting the Old Age Crisis (Oxford University Press, New York).

World Bank (1995). Mauritius Country Economic Memorandum: Sharpening the Competitive Edge (Report No. 13215-MAS, Washington, D.C., April 12). 
Appendix A. Coverage and Cost of Basic Pensions in Mauritius, 1950-2001.

\begin{tabular}{|c|c|c|c|c|c|c|c|}
\hline Year ending December & (Rs $\frac{\text { GDP }}{\text { million) }}$ & $\begin{array}{c}\text { Elderly } \\
\text { Persons }\end{array}$ & Pensioners & $\begin{array}{l}\text { Average } \\
\text { pension } \\
\text { (Rs 000) }\end{array}$ & $\begin{array}{l}\text { Per capita } \\
\text { GDP } \\
\text { (Rs 000) }\end{array}$ & $\begin{array}{l}\text { Consumer } \\
\text { Price Index } \\
(\mathrm{CPI})\end{array}$ & $\begin{array}{c}\text { Pension } \\
\text { Costs } \\
(\% \text { of GDP) }\end{array}$ \\
\hline 1950 & 577.9 & 15440 & 10545 & 80 & 1201 & & 0.29 \\
\hline 1951 & 653.4 & 16052 & 13965 & 168 & 1311 & & 0.36 \\
\hline 1952 & 737.9 & 16641 & 12304 & 179 & 1429 & & 0.30 \\
\hline 1953 & 752.1 & 24075 & 19002 & 167 & 1403 & & 0.42 \\
\hline 1954 & 751.9 & 24673 & 20456 & 211 & 1357 & & 0.57 \\
\hline 1955 & 716.7 & 25093 & 18429 & 239 & 1254 & & 0.61 \\
\hline 1956 & 840.5 & 24367 & 19031 & 234 & 1420 & & 0.53 \\
\hline 1957 & 877.3 & 24584 & 19607 & 236 & 1439 & & 0.53 \\
\hline 1958 & 781.8 & 25883 & 25783 & 303 & 1246 & & 1.00 \\
\hline 1959 & 823.9 & 26303 & 26714 & 262 & 1511 & & 0.85 \\
\hline 1960 & 761.6 & 26788 & N/A & $\mathrm{N} / \mathrm{A}$ & 1148 & & $\mathrm{~N} / \mathrm{A}$ \\
\hline 1961 & 901.0 & 28635 & 28407 & $\mathrm{~N} / \mathrm{A}$ & 1324 & & $\mathrm{~N} / \mathrm{A}$ \\
\hline 1962 & 929.1 & 30984 & 29355 & 263 & 1327 & & 0.83 \\
\hline 1963 & 1192.7 & 32366 & N/A & $\mathrm{N} / \mathrm{A}$ & 1670 & 6.94 & $\mathrm{~N} / \mathrm{A}$ \\
\hline 1964 & 1028.6 & 33731 & 31430 & 264 & 1399 & 7.07 & 0.81 \\
\hline 1965 & 1080.8 & 43181 & 38064 & 260 & 1432 & 7.19 & 0.92 \\
\hline 1966 & 1069.1 & 44205 & 39198 & 265 & 1382 & 7.37 & 0.97 \\
\hline 1967 & 1135.9 & 45623 & 40393 & 267 & 1441 & 7.51 & 0.95 \\
\hline 1968 & 1132.4 & 46751 & 41760 & 266 & 1409 & 8.04 & 0.98 \\
\hline 1969 & 1214.5 & 47513 & 42670 & 267 & 1490 & 8.22 & 0.94 \\
\hline 1970 & 1228.6 & 48563 & 43761 & 270 & 1482 & 8.35 & 0.96 \\
\hline 1971 & 1361.0 & 49670 & 46625 & 266 & 1619 & 8.38 & 0.91 \\
\hline 1972 & 1678.6 & 51525 & 47482 & 305 & 1973 & & 0.86 \\
\hline 1973 & 2171.0 & 54118 & 49038 & 326 & 2497 & & 0.74 \\
\hline \multicolumn{8}{|l|}{ Fiscal year ending June } \\
\hline 1972 & 1520 & 50200 & 46747 & 289 & 1796 & 8.83 & 0.89 \\
\hline 1973 & 1925 & 52849 & 48279 & 298 & 2235 & 10.01 & 0.75 \\
\hline 1974 & 2970 & 55386 & 49592 & 391 & 3389 & 12.93 & 0.65 \\
\hline 1975 & 3887 & 57300 & 52415 & 485 & 4385 & 14.84 & 0.65 \\
\hline 1976 & 4354 & 58021 & 53895 & 668 & 4847 & 16.76 & 0.83 \\
\hline 1977 & 5073 & 59664 & 58348 & 965 & 5567 & 18.29 & 1.11 \\
\hline 1978 & 5850 & 60943 & 60012 & 1158 & 6316 & 19.86 & 1.19 \\
\hline 1979 & 6949 & 62404 & 61631 & 1266 & 7373 & 22.73 & 1.12 \\
\hline 1980 & 8168 & 63459 & 63000 & 1298 & 8523 & 32.28 & 1.00 \\
\hline 1981 & 9453 & 65730 & $\mathrm{~N} / \mathrm{A}$ & NA & 9708 & 36.95 & $\mathrm{~N} / \mathrm{A}$ \\
\hline 1982 & 10967 & 67704 & $\mathrm{~N} / \mathrm{A}$ & NA & 11113 & 41.16 & $\mathrm{~N} / \mathrm{A}$ \\
\hline 1983 & 12244 & 70277 & $\mathrm{~N} / \mathrm{A}$ & NA & 12277 & 43.46 & $\mathrm{~N} / \mathrm{A}$ \\
\hline 1984 & 13562 & 72461 & $\mathrm{~N} / \mathrm{A}$ & NA & 13464 & 46.68 & $\mathrm{~N} / \mathrm{A}$ \\
\hline 1985 & 15489 & 75528 & 74168 & 2277 & 15235 & 49.80 & 1.09 \\
\hline 1986 & 18159 & 78453 & 77957 & 2574 & 17720 & 50.62 & 1.11 \\
\hline 1987 & 21961 & 80503 & 80811 & 2762 & 21268 & 50.88 & 1.02 \\
\hline 1988 & 26452 & 82253 & 83102 & 3244 & 25436 & 55.54 & 1.02 \\
\hline 1989 & 30978 & 84681 & 85641 & 3835 & 29573 & 62.57 & 1.06 \\
\hline 1990 & 36451 & 87527 & 87195 & 4264 & 34540 & 71.01 & 1.02 \\
\hline 1991 & 41973 & 88605 & 89274 & 5914 & 39420 & 75.99 & 1.26 \\
\hline 1992 & 46975 & 89513 & 91208 & 7284 & 43591 & 79.51 & 1.41 \\
\hline 1993 & 53102 & 91248 & 92950 & 7959 & 48662 & 87.88 & 1.39 \\
\hline 1994 & 59807 & 93457 & 96254 & 8704 & 54108 & 94.31 & 1.40 \\
\hline 1995 & 66063 & 95393 & 101665 & 9666 & 59113 & 100.00 & 1.49 \\
\hline 1996 & 73196 & 97528 & 103804 & 11470 & 64883 & 106.55 & 1.63 \\
\hline 1997 & 81869 & 99272 & 107106 & 14781 & 71753 & 113.83 & 1.93 \\
\hline
\end{tabular}


Appendix A (concluded).

\begin{tabular}{|c|c|c|c|c|c|c|}
\hline GDP & $\begin{array}{c}\text { Elderly } \\
\text { Persons }\end{array}$ & ensione & $\begin{array}{l}\text { Average } \\
\text { pension } \\
(\text { Rs 000) }\end{array}$ & $\begin{array}{l}\text { Per capita } \\
\text { GDP } \\
(\text { Rs 000) }\end{array}$ & $\begin{array}{l}\text { Consumer } \\
\frac{\text { Price Index }}{(\mathrm{CPI})}\end{array}$ & $\begin{array}{c}\text { Pension } \\
\text { Costs } \\
(\% \text { of GDP) }\end{array}$ \\
\hline
\end{tabular}

Fiscal year ending June

$\begin{array}{lccccccc}1998 & 93159 & 101274 & 108784 & 16222 & 80719 & 121.59 & 1.89 \\ 1999 & 103667 & 102748 & 109571 & 18689 & 88810 & 129.99 & 1.98 \\ 2000 & 113265 & 105234 & 111885 & 19738 & 95953 & 135.44 & 1.95 \\ 2001 & 125608 & 109180 & 113051 & 21976 & 105269 & 142.70 & 1.98\end{array}$

Note: Elderly persons are defined by the qualifying age for pensions, 65 years in 1950, lowered to 60 years for females in 1953 , to 60 years for males commencing in 1965 .

Source: Author's estimates, based on data from varied publications of the Central Statistical Office and the Ministry of Social Security of Mauritius and (for CPI only) International Financial Statistics of the IMF. 


\section{DESA Discussion Papers}

No. 1 Public versus Private Provision of Pensions, By Larry Willmore, December 1998

No. 2 Inefficiencies of Global Capital Markets, By Hugh Stretton, December 1998

No. 3 Greening the National Accounts: Approach and Policy Use, By Peter Bartelmus, January 1999

No. 4 Unpaid Work and Policy-Making Towards a Broader Perspective of Work and Employment By Joke Swiebel, February 1999

No. 5 Trends in Consumption and Production: Selected Minerals, By Oleg Dzioubinski and Ralph Chipman, March 1999

No. 6 Trends in Consumption and Production: Household Energy Consumption By Oleg Dzioubinski and Ralph Chipman, April 1999

No. 7 Promoting Sustainable Production and Consumption: Five Policy Studies By Tarcisio Alvarez-Rivero, Ralph Chipman and Erik Bryld, April 1999

No. 8 Regulation Policies Concerning Natural Monopolies in Developing and Transition Economies By S. Ran Kim and A. Horn, March 1999

No. 9 Tourism development in the Lao People's Democratic Republic, By Sayo Yamauchi and Donald Lee, June 1999

No.10 Import Elasticities Revisited, By Pingfan Hong, September 1999

No.11 Resources for Social Development: Additional and Innovative Resources, By Anthony Clunies-Ross, March 2000

No.12 Export Processing Zones in Cuba, By Larry Willmore, May 2000

No.13 Three Pillars of Pensions? A Proposal to End Mandatory Contributions, By Larry Willmore, June 2000

No.14 The Underlying Constraints on Corporate Bond Market Development in Southeast Asia By Krishnan Sharma, September 2000

No.15 Bank-firm Cross-shareholding in Japan: What is it, why does it matter, is it winding down? By Mark J. Scher, February 2001

No.16 The Supply of Credit by Multinational Banks in Developing and Transition Economies: Determinants and Effects, By Christian E. Weller, March 2001

No.17 Global Implications of the United States Trade Deficit Adjustment, By Pingfan Hong, February 2001

No.18 Price Stability in a Monetary Union, By Stefania Piffanelli, September 2001

No.19 The Instrument of Monetary Policy for Germany. A Structural VAR Approach, By Stefania Piffanelli, September 2001

No.20 Preventing Civil Strife: An Important Role for Economic Policy, By Henk-Jan Brinkman, September 2001

No.21 Government Policies toward Information and Communication Technologies: A Historical Perspective By Larry Willmore, October 2001

No.22 Postal Savings and the Provision of Financial Services: Policy Issues and Asian Experiences in the Use of the Postal Infrastructure for Savings Mobilization, By Mark J. Scher, December 2001

No.23 Strengthening Information and Analysis in the Global Financial System: A Concrete Set of Proposals, By Barbara Samuels, II, June 2002

No.24 Multisectoral Global Funds as instruments for financing spending on global priorities By Jeremy J. Heimans, September 2002

No.25 GATS and its implications for Developing Countries: Key Issues and Concerns, By Rupa Chanda, November 2002

No.26 Informal Money Transfer Systems: Opportunities and Challenges for Development Finance By Leonides Buencamino and Sergei Gorbunov, November 2002

No.27 Education by the State, By Larry Willmore, November 2002

No.28 Capital Markets Financing for Developing-Country Infrastructure Projects, By Robert Sheppard, January 2003

No.29A New Approach to Sustainable Tourism Development: Moving Beyond Environmental Protection, By Frederico Neto, March 2003

No. 30 The Role of Decentralized Governance in Fostering the Participation of Minorities, By Guido Bertucci and Adriana Alberti, March 2003

No. 31 The Efficacy of Regulation in Developing Countries, By Seema Hafeez, April 2003

No. 32 Universal Pensions in Mauritius: Lessons for the Rest of Us, By Larry Willmore, April 2003

DESA Discussion Papers are posted on the DESA web site: http://www.un.org/esa/papers.htm 